\title{
Alaska Resource Data File, Chignik quadrangle, Alaska
}

By Steven H. Pilcher 1

Open-File Report 00-130

2000

This report is preliminary and has not been reviewed for conformity with U.S. Geological Survey editorial standards or with the North American Stratigraphic Code. Any use of trade, firm, or product names is for descriptive purposes only and does not imply endorsement by the U.S. Government.

U.S. DEPARTMENT OF THE INTERIOR

U.S. GEOLOGICAL SURVEY

${ }^{1}$ Anchorage, Alaska 


\section{Chignik quadrangle}

Descriptions of the mineral occurrences shown on the accompanying figure follow. See U.S. Geological Survey (1996) for a description of the information content of each field in the records. The data presented here are maintained as part of a statewide database on mines, prospects and mineral occurrences throughout Alaska.

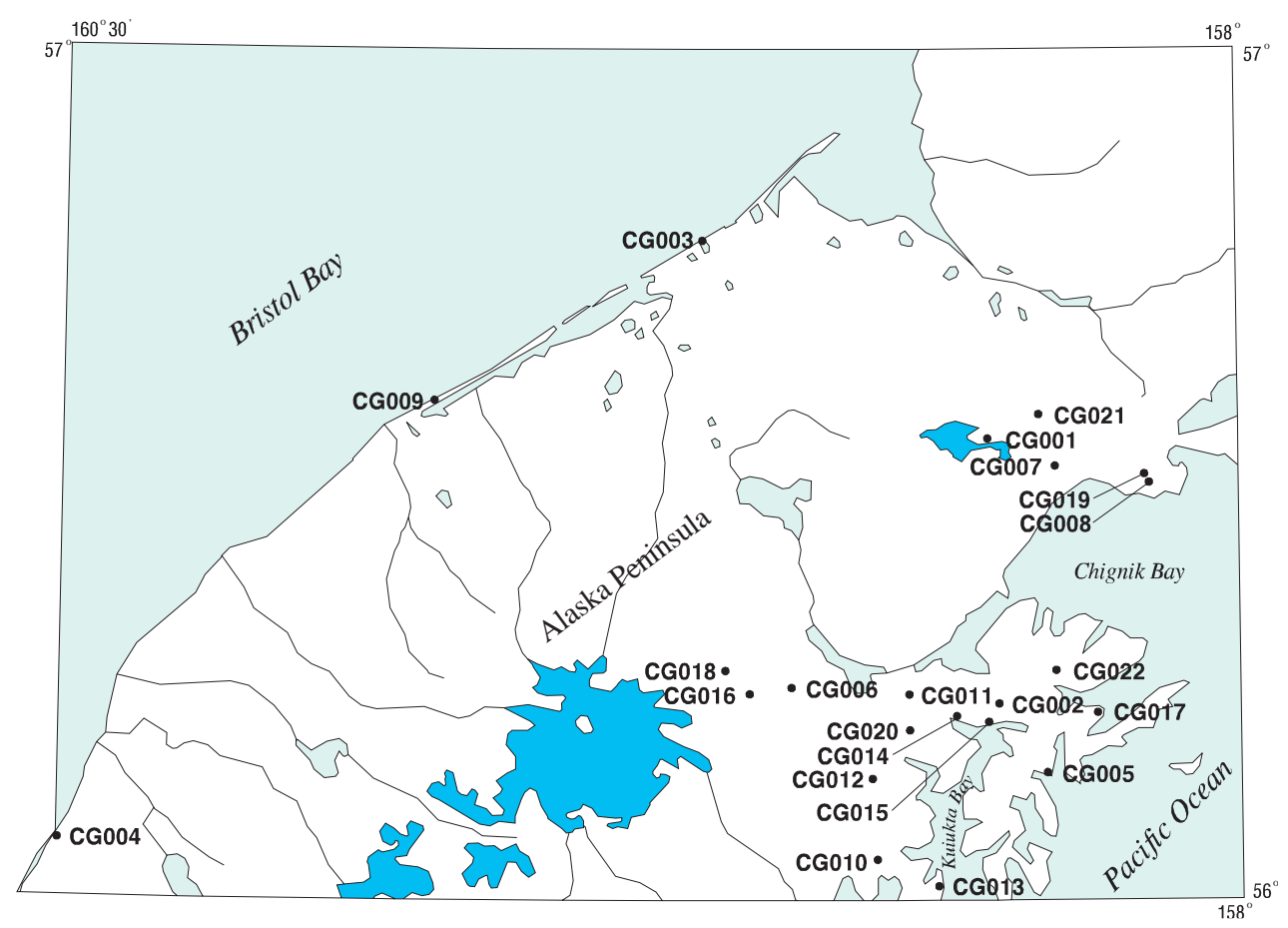

Distribution of mineral occurrences in the Chignik 1:250,000-scale quadrangle, Alaska Peninsula, Alaska

This and related reports are accessible through the USGS World Wide Web site http://ardf.wr.usgs.gov. Comments or information regarding corrections or missing data, or requests for digital retrievals should be directed to: Frederic Wilson, USGS, 4200 University Dr., Anchorage, AK 99508-4667, e-mail fwilson@usgs.gov, telephone (907) 786-7448. This compilation is authored by:

Steven H. Pilcher Anchorage, AK

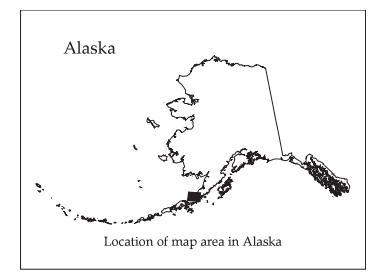

This report is preliminary and has not been reviewed for conformity with U.S. Geological Survey editorial standards or with the North American Stratigraphic code. Any use of trade, product, or firm names is for descriptive purposes only and does not imply endorsement by the U.S. Government. 


\section{Site name(s): Braided Creeks; Cathedral Creek; Manhattan}

Site type: Prospect

ARDF no.: CG001

Latitude: 56.527

Quadrangle: CG C-2

Longitude: 158.573

\section{Location description and accuracy:}

This site represents a large color anomaly. The anomaly is approximately 3 miles northsouth and 9 miles east-west, covering parts of T. 42 S., R. 59 and 60 W., of the Seward Meridian, encompassing the headwaters of Milk, Cathedral, and Braided Creeks (Cobb, 1972: MF-374, locality 1; U.S. Bureau of Mines, 1973, localilties 11, 12, 14, 15, and 18; MacKevett and Holloway, 1977, localities 1, 8-16, 18, and 19; Cox and others, 1981, locality 2; Nokleberg and others, 1987, locality AP 10). The map site is plotted at the location of the Manhattan prospect, near the headwaters of Braided Creek (map C-2). The location is accurate to within $1 / 2$ mile.

\section{Commodities:}

Main: $\mathrm{Ag}, \mathrm{Au}, \mathrm{Cu}, \mathrm{Pb}, \mathrm{Zn}$

Other: As

Ore minerals: Arsenopyrite, chalcopyrite, galena, gold, pyrargyrite, pyrite, pyrrhotite, sphalerite, tetrahedrite

Gangue minerals: Dolomite, quartz

\section{Geologic description:}

Rocks in this prospect area include a large diorite stock of Oligocene age and smaller andesite and dacite plug domes of Miocene and Oligocene ages. The diorite stock cuts dacite flows of Oligocene age and sedimentary rocks of the Meshik Formation (Detterman and others, 1981).

Mineralization within the main part of the stock has been described as a large, discontinuous sulfide system with low order copper and molybdenum anomalies (Fields, 1977). Cathedral and Milk Creeks drain an area distinguished by a cluster of silt samples containing anomalous values in copper and molybdenum. Fields, however, did not report any outcropping copper-molybdenum mineralization in this area, although chalcopyrite in quartz-chlorite veins was found in float. Nokleberg and others (1987) reported the occurrence of copper and molybdenite in zones of sericitic alteration within intrusives in the area.

Pervasive pyrite ( 2 to 7 percent) is present in the sedimentary rocks and to a minor de- 
gree in the volcanic rocks peripheral to the stock. In some areas the pyrite is accompanied by epidote, chlorite, and clay alteration. Other areas exhibit pervasive sericitization.

In the eastern part of the area of the color anomaly, base and precious metal veins crop out at the Manhattan prospect, near the headwaters of Braided Creek. Approximately 20 veins have been discovered, traceable for up to 700 feet on strike. These are up to several feet in thickness and contain arsenopyrite, chalcopyrite, galena, gold, pyrargyrite, pyrite, pyrrhotite, quartz, sphalerite, and tetrahedrite. The veins cut the Chignik Formation and dacite porphyry. They trend $\mathrm{N} 20$ to $45 \mathrm{E}$ It has been suggested that these veins represent a peripheral zone to the Cathedral Creek sulfide system (Wilson and Cox, 1983).

At the Manhattan prospect Pan American Exploration (now Amoco) carried out geophysical surveys and drilled 14 holes for a total of 2,539 meters in 1965-1967. Bear Creek Mining Company briefly explored the area in 1975. In 1979 Resource Associates of Alaska sampled a 2-3 foot thick vein traceable for 700 feet. Their assay results are as follows: copper to $2400 \mathrm{ppm}$, gold to 0.596 ounce per ton, lead to 1.06 percent, silver to 16.29 ounces per ton, zinc to 9.5 percent (Anderson and others, 1979). In 1984 Anaconda drilled approximately 6 holes on this vein system. They reported metal values of 0.25 to 0.5 ounce gold per ton, 1 to 10 ounces silver per ton, and 5 to 10 percent lead-zinc.

Young and others (1997) estimate a resource at the Manhattan prospect of 90,000 to 180,000 tonnes grading 0.6 ounce gold per ton, 10 ounces silver per ton, and 15 percent lead-zinc. Subsequent owners claim a resource of 575,000 tons grading 0.39 ounce gold equivalent per ton (Alaska Earth Science, 1997).

\section{Alteration:}

The sedimentary rocks peripheral to the stock exhibit pervasive sericitization in some areas and epidote, chlorite, clay alteration in others. Chloritization in the stock is common and localized areas of quartz-sericite alteration have been reported.

\section{Age of mineralization:}

Tertiary or younger.

\section{Deposit model:}

Polymetallic vein and possible upper level of a prophyry copper system (Cox and Singer, 1986; models 22c and 17?)

\section{Deposit model number (After Cox and Singer, 1986 or Bliss, 1992):}

$22 \mathrm{c}$ and 17 ?

\section{Production Status: None}

Site Status: Inactive

\section{Workings/exploration:}

Fourteen holes were drilled at the Manhatten prospect on Braided Creek by Pan American Exploration in 1965-67 for a total of 2539 meters. Bear Creek Mining Company examined and sampled the prospect for 3 days in 1975. Resource Associates of Alaska sampled a polymetallic vein here in 1979. Anaconda drilled approximately 6 holes on the 
Braided Creek showings in 1984.

Sampling of 1 vein by Resource Associates of Alaska assayed as follows: copper to $2400 \mathrm{ppm}$, gold to 0.596 ounce per ton, lead to 1.06 percent, silver to 16.29 ounces per ton, and zinc to 9.5 percent. Anaconda reported metal values of 0.25 to 0.5 ounce gold per ton, 1 to 10 ounces silver per ton, and 5 to 10 percent lead-zinc.

\section{Production notes:}

\section{Reserves:}

Young and others (1997) list a resource of 90,000 to 180,000 tonnes grading 10 ounces silver per ton, 0.6 ounces gold per ton, and 15 percent lead-zinc. Subsequent owners claim 575,000 tons grading 0.39 ounce gold equivalent per ton (Alaska Earth Science, 1997).

\section{Additional comments:}

This site is located in Alaska Peninsula National Wildlife Refuge.

\section{References:}

Brown and others, 1965; Cobb, 1972 (MF-374); U.S. Bureau of Mines, 1973; MacKevett and Holloway, 1977; Fields, 1977; Anderson and others, 1979; Cobb, 1980 (OFR 80909); Wilson, 1980; Cox and others, 1981; Detterman and others, 1981; Wilson and Cox, 1983; Nokleberg and others, 1987; Alaska Earth Science, 1997; Young and others, 1997.

Primary reference: Wilson and Cox, 1983

Reporter(s): S.H. Pilcher (Anchorage)

Last report date: $2 / 8 / 00$ 


\section{Site name(s): Mallard Duck Bay; Calcite; Marshinlak}

Site type: Occurrences

ARDF no.: CG002

Latitude: 56.231

Quadrangle: CG A-2

Longitude: 158.511

\section{Location description and accuracy:}

This site represents an area southeast of Chignik Lagoon at the head of Mallard Duck Bay (Berg and Cobb, 1967, locality 2; Cobb, 1972: MF-374, locality 2; MacKevett and Holloway, 1977, locality 2; Cox and others, 1981, locality 8; Nokleberg and others, 1987, locality AP 11). The map site is plotted at an elevation of about 1000 feet, about 0.2 miles southeast of the head of Mallard Duch Bay. The location is accurate to within 1/4 mile.

\section{Commodities:}

Main: $\mathrm{Ag}, \mathrm{Au}, \mathrm{Cu}, \mathrm{Mo}, \mathrm{Pb}, \mathrm{Zn}$

Other: As

Ore minerals: Arsenopyrite, chalcopyrite, galena, gold, pyrite, sphalerite

Gangue minerals: Calcite, quartz, siderite

\section{Geologic description:}

This site represents a large propylitically altered zone covering an area 6 miles by $21 / 2$ miles at the head of Mallard Duck Bay (Wilson and Cox, 1983). Elevation of the zone varies from sea level to 600 meters. The altered zone is associated with widespread introduction of pyrite and with low-order drainage anomalies (60 ppm copper, 15 ppm molybdenum, 0.3 ppm silver).

Rock types include diorite stocks up to 2000 feet in diameter and a system of northeasttrending quartz-diorite dikes which are up to $1 / 2$ mile in length and up to several hundred feet in thickness. A system of andesite dikes trends N 30 to $40 \mathrm{~W}$ and dips vertically across a 4000-foot wide zone. All of these intrusives cut Eocene-Oligocene volcanics of the Meshik Formation which consists of andesite and basalt flows, volcaniclastic breccias, volcaniclastic sediments, and tuffaceous units.

Within the large area of propylitized rock is a zone of intense argillic alteration which covers an area of approximately 2 miles by $1 / 2$ mile. This is referred to as the central argillic zone (Anderson and others 1979). The argillic alteration appears to be related to the northwest-trending andesite dikes because it forms envelopes up to 100 feet wide on either side of the dikes. The altered areas exhibit some silicification and introduction of disseminated pyrite. They also contain coarse stockworks of fractures, some of which con- 
tain quartz, pyrite, and rarely molybdenite.

Molybdenum mineralization occurs primarily in a stockwork that lies between two parallel andesite dikes outside of the central argillic zone. The mineralized rock is limonitic and exihibits silicification and minor argillization. As the dikes are approached the alteration increases and the molybdenum mineralization decreases (Anderson and others, 1979). The molybdenum zone has been traced for 100 feet but the total length is unknown. Fields (1977) notes molybdenum values ranging from 2 to 99 ppm in rock samples.

Systems of northwest-trending polymetallic veins are present in the propylitized volcanics. The Calcite and Mallard Duck vein systems occur in an area 1/2 to 1 mile southwest of the central argillic zone. Individual veins are up to 800 feet long and 10 feet wide. Other veins are known to extend along this trend for over 4 miles northwest to the beach exposures at Mallard Duck Bay. The Marshinlak vein system is located approximately 2 miles north of the central argillic zone and has been traced intermittently for over 6500 feet in a northwest direction. These veins are up to 15 feet in thickness. Minor strike trends include northeast, north-south, and east-west. The veins vary in composition from quartz to quartz-calcite to quartz-siderite and may carry up to 5 percent sulfides, including arsenopyrite, chalcopyrite, galena, pyrite, and sphalerite. Some veins exhibit cockscomb features and some show evidence of repetitive pulsing of quartz and sulfides.

Metal values in the Calcite and Mallard Duck systems range as follows: $3360 \mathrm{ppm}$ to 4.2 percent copper, < $0.02 \mathrm{ppm}$ to $3.3 \mathrm{ppm}$ gold, $1100 \mathrm{ppm}$ to 4.45 percent lead, $20 \mathrm{ppm}$ to 21 ounces silver ounces per ton, $1100 \mathrm{ppm}$ to 22.7 percent zinc (Butherus and others, 1981). Trace amounts of antimony and mercury were also detected. Copper, lead, and zinc values obtained in the Marshinlak system were all less than $100 \mathrm{ppm}$. Gold values ranged from $0.48 \mathrm{ppm}$ to 0.163 ounce per ton and silver values from $3.4 \mathrm{ppm}$ to 0.54 ounce per ton.

\section{Alteration:}

Propylitically altered volcanics cover an area of approximately 6 by $21 / 2$ miles. Within this altered zone argillic alteration forms envelopes up to 100 feet wide peripheral to northwest-trending andesite dikes, resulting in a central argillic zone which covers an area of approximately 2 by $1 / 2$ miles.

\section{Age of mineralization:}

The probable age of mineralization is estimated at 21-27 million years (Cox and others, 1981).

\section{Deposit model:}

Porphyry copper; porphyry copper-molybdenum; polymetallic veins (Cox and Singer, 1986; models 17, 21a, 22c)

\section{Deposit model number (After Cox and Singer, 1986 or Bliss, 1992):}

17, 21a, 22c

Production Status: None 
Site Status: Inactive

\section{Workings/exploration:}

Gold claims were staked in the early part of the century. Bear Creek Mining Company mapped and sampled this zone in 1975 and 1976. Resource Associates of Alaska did detailed mapping and sampling in 1979, 1981, and 1982.

\section{Production notes:}

\section{Reserves:}

\section{Additional comments:}

This site is on land patented by or interim conveyed to the Bristol Bay Native Corporation.

\section{References:}

Atwood, 1911; Berg and Cobb, 1967; Cobb, 1972 (MF-374); MacKevett and Holloway, 1977; Fields, 1977; Anderson and others, 1979; Wilson, 1980; Cobb, 1980 (OFR 80909); Butherus and others, 1981; Cox and others, 1981; Detterman and others, 1981; Wilson and Cox, 1983; Nokleberg and others, 1987.

Primary reference: Anderson and others, 1979

Reporter(s): S.H. Pilcher (Anchorage)

Last report date: $2 / 8 / 00$ 


\section{Site name(s): Port Heiden}

Site type: Occurrence

ARDF no.: CG003

Latitude: 56.8

Quadrangle: CG D-4

Longitude: 159.1

\section{Location description and accuracy:}

This site represents 20 miles of beach placers on the northwest coast of the Alaska Peninsula between the Seal Islands and Port Heiden (Cobb, 1973: B-1374, locality 5; MacKevett and Holloway, 1977, locality 4; Cobb, 1980: OFR 80-909, locality 4).

\section{Commodities:}

Main: $\mathrm{Fe}, \mathrm{Ti}$

Other: $\mathrm{Au}$

Ore minerals: Gold, ilmenite, magnetite

\section{Gangue minerals:}

\section{Geologic description:}

This occurrence consists of beach placer deposits of ilmenite and titaniferous magnetite in narrow spits and bars along the outer shores of low-lying mudflats. The beaches are sandy gravel, often loosely packed.

Twenty-four auger samples were collected along this 20-mile section (Berryhill, 1963). They were screened, tabled, and run through a magnetic separator. In the magnetic fraction iron content ranged from 2.2 to 103.6 pounds per cubic yard, and the titanium oxide content ranged from 0.6 to 21.9 pounds. In the non-magnetic fraction the titanium oxide content ranged from 0 to 1.2 pounds per cubic yard. A trace of flour gold was present in 5 samples.

\section{Alteration:}

Age of mineralization:

Quaternary.

\section{Deposit model:}

Shoreline placer titanium (Cox and Singer, 1986; model 39c)

Deposit model number (After Cox and Singer, 1986 or Bliss, 1992): 
$39 \mathrm{c}$

Production Status: None

Site Status: Inactive

Workings/exploration:

The magnetic fraction of 24 auger samples collected in 1963 contained 2.2 to 103.6 pounds iron and 0.6 to 21.9 pounds titanium oxide per cubic yard. The non-magnetic fraction contained 0 to 1.2 pounds titanium oxide per cubic yard.

\section{Production notes:}

\section{Reserves:}

\section{Additional comments:}

This site is located on state land, part of which is in the Port Heiden Critical Habitat Area.

\section{References:}

Berryhill, 1963; Cobb, 1972 (MF-374); Cobb, 1973 (B-1374); MacKevett and Holloway, 1977; Cobb, 1980 (OFR 80-909).

Primary reference: Berryhill, 1963

Reporter(s): S.H. Pilcher (Anchorage)

Last report date: $2 / 8 / 00$ 
Site name(s): Port Moller

Site type: Occurrence

ARDF no.: CG004

Latitude: 56.1

Quadrangle: CG A-8

Longitude: 160.5

\section{Location description and accuracy:}

This site represents 5 miles of beach placer deposits on the northwest coast of the Alaska Peninsula extending for approximately 5 miles southwest of Franks Lagoon onto the Port Moller 1:250,000-scale map sheet (Cobb, 1973: B-1374, locality 3; MacKevett and Holloway, 1977, locality 4). The maps site is plotted at Franks Lagoon.

\section{Commodities:}

Main: $\mathrm{Fe}, \mathrm{Ti}$

Other: $\mathrm{Au}$ ?

Ore minerals: Gold?, ilmenite, magnetite

\section{Gangue minerals:}

\section{Geologic description:}

This occurrence consists of beach placer deposits of magnetite and titaniferous ilmenite in well-developed sandy spits extending 5 miles southwest of Franks Lagoon.

Berryhill (1963) collected 11 auger samples and a few shovel samples along this 5-mile section of beach. These samples were screened, tabled, and run through a magnetic separater. The magnetic fraction contained 1.1 to 191.4 pounds iron per cubic yard and 0.3 to 42.2 pounds titanium oxide. The non-magnetic fraction contained 0 to 10.3 pounds per cubic yard titanium oxide.

\section{Alteration:}

\section{Age of mineralization:}

Quaternary.

\section{Deposit model:}

Shoreline placer titanium (Cox and Singer, 1986; model 39c)

Deposit model number (After Cox and Singer, 1986 or Bliss, 1992): $39 \mathrm{c}$ 
Production Status: None

Site Status: Inactive

Workings/exploration:

The magnetitic fraction of 11 auger and shovel samples collected in 1963 contained 1.1 to 191.4 pounds iron and 0.3 to 42.2 pounds titanium oxide per cubic yard. The nonmagnetic fraction contained 0 to 10.3 pounds titanium oxide per cubic yard.

\section{Production notes:}

Reserves:

Additional comments:

This site is located on state land.

\section{References:}

Berryhill, 1963; Cobb, 1973 (MF-374); MacKevett and Holloway, 1977; Cobb, 1980 (OFR 80-909).

Primary reference: Berryhill, 1963

Reporter(s): S.H. Pilcher (Anchorage)

Last report date: $2 / 8 / 00$ 


\section{Site name(s): Warner Bay; Prospect Bay}

Site type: Prospect

ARDF no.: CG005

Latitude: 56.15

Quadrangle: CG A-2

Longitude: 158.41

\section{Location description and accuracy:}

This site is at or near sea level on the west side of Warner Bay just to the south of the spit (Berg and Cobb, 1967, locality 3; Cobb, 1972: MF-374; Cobb, 1980: OFR 80-909, locality 3; MacKevett and Holloway, 1977, locality 3; Cox and others, 1981, locality 11; Nokleberg and others, 1987, locality AP 9). Site location as plotted is accurate to within 1 mile.

\section{Commodities:}

Main: $\mathrm{Ag}, \mathrm{Au}, \mathrm{Cu}, \mathrm{Mo}, \mathrm{Pb}, \mathrm{Zn}$

Other: Sn, W

Ore minerals: Chalcopyrite, galena, gold, molybdenite, pyrite, sphalerite, wolframite?

Gangue minerals: Calcite, chlorite, hematite, quartz, zeolites

\section{Geologic description:}

This prospect is within the northeast part of the Devils Bay batholith (Detterman and others, 1981). This pluton is a multiphase granodiorite to tonalite which intrudes sediments of the Cretaceous Hoodo Formation. Potassium-argon dates of the pluton indicate a range of between 5 and 10 million years (Wilson, 1980).

Atwood (1911) first described this prospect as a 50-foot wide crushed zone containing chalcopyrite, galena, pyrite, quartz and sphalerite. Later, more extensive investigation has shown that mineralization is exposed mostly in vertical cliffs extending down to sea level. Chalcopyrite and molybdenite occur as veinlets on joint surfaces spaced 5 to 10 centimeters apart (Cox and others, 1981). The extent of this mineralization has not been reported. Four samples collected by Resource Associates of Alaska in 1979 assayed as follows: 520 to $16,000 \mathrm{ppm}$ copper, 280 to $9,110 \mathrm{ppm}$ molybdenum, 0.4 to $2.5 \mathrm{ppm}$ silver, $20 \mathrm{ppm}$ tin, and 9-128 ppm tungsten. Cox and others (1981) list the grade of this mineralization at 0 to 0.07 percent molybdenum with a trace of copper. Nokleberg and others (1987) list an average grade of 0.03 percent copper with values up to 0.7 percent.

Massive sulfide veins, ranging in width from 2 inches to 4 feet occur filling a northwest-trending nearly vertical fracture system. These are spaced approximately 100 feet apart over a distance of 3500 feet along the beach. Assays of this material by Resource 
Associates of Alaska returned values of up to 5.7 percent copper, 0.312 ounce gold per ton, 0.91 percent molybdenum, 1.25 percent lead, 395 ppm tungsten, and 10.8 percent zinc (Anderson and others, 1979). One sample reported 3000 ppm lanthanum.

A breccia pipe, approximately 3 meters in diameter, occurs at the extreme north end of the showing. It contains clasts of propylitically altered granodiorite cemented by galena, pyrite, sphalerite, calcite, chlorite, and zeolites. The small tonnage in sight is estimated at $>10,000$ tonnes. Anderson and others (1979) give values for a high-grade sample as follows: 1600 ppm copper, 0.1 ppm gold, 4000 ppm lead, 2.3 ppm silver, 8 ppm tungsten, 400 ppm zinc.

Four holes were drilled on the prospect in 1965 and 1966 by Pan American Exploration (now Amoco) for a total of 2432 feet Cobb (1980: OFR 80-909) reports drilling as recent as 1977.

\section{Alteration:}

Alteration of granodiorite host rock is limited to partial alteration (?) of amphibole to biotite and slight chloritization of biotite. Clasts of granodiorite in the breccia pipe exhibit propylitic alteration. Biotitic and sericitic alteration occur as thin selvages along veinlets.

\section{Age of mineralization:}

The age of mineralization is estimated at less than 6.5 million years (Wilson, 1980).

\section{Deposit model:}

Porphyry copper-molybdenum; polymetallic vein (Cox and Singer, 1986; models 21a, 22c)

\section{Deposit model number (After Cox and Singer, 1986 or Bliss, 1992):} $21 \mathrm{a}, 22 \mathrm{c}$

\section{Production Status: None}

Site Status: Inactive

\section{Workings/exploration:}

Two short adits were driven in the early 1900's (Atwood, 1911). In the 1960's four holes were drilled for a total of 2432 feet. Some drilling has been reported as late as 1977. Bear Creek Mining Company visited the property in 1975 and Resource Associates mapped and sampled there in 1979.

\section{Production notes:}

\section{Reserves:}

\section{Additional comments:}

This site is located on land patented by or interim conveyed to the Bristol Bay Native Corporation. 
References:

Atwood, 1909; Atwood, 1911; Knappen, 1929; Berg and Cobb, 1967; Cobb, 1972 (MF374); Fields, 1977; MacKevett and Holloway, 1977; Anderson and others, 1979; Cobb, 1980 (OFR 80-909); Wilson, 1980; Cox and others, 1981; Detterman and others, 1981; Wilson and Cox, 1983; Nokleberg and others, 1987.

Primary reference: Wilson and Cox, 1983

Reporter(s): S.H. Pilcher (Anchorage)

Last report date: $2 / 8 / 00$ 


\section{Site name(s): Bearskin Gulch}

Site type: Occurrence

ARDF no.: CG006

Latitude: 56.25

Quadrangle: CG B-3

Longitude: 158.95

\section{Location description and accuracy:}

This site represents an area of approximately 8 square miles in T. $45 \mathrm{~S}$., R. $62 \mathrm{~W}$., of the Seward Meridian, covering the headwaters of both the east and west forks of Bearskin Creek (Cox and others, 1981, locality 6). The map site is plotted at an elevation of 1200 feet at the head of the east branch of Bearskin Gulch, which is at the head of Bearskin Creek. The location is accurate to within 2 miles.

\section{Commodities:}

Main: $\mathrm{Ag}, \mathrm{Au}, \mathrm{Cu}, \mathrm{Mo}$

\section{Other:}

Ore minerals: Chalcopyrite, gold, molybdenite, pyrite

\section{Gangue minerals:}

\section{Geologic description:}

The Jurassic Naknek Formation is the main rock unit exposed at the site (Detterman and others, 1981). It consists of graywacke, siliceous siltstone, hornfels, quartzite, and minor grit. The strata strike N 20 to $45 \mathrm{E}$, and dip 28 to 40 southeast. A small (1000 feet diameter) weakly-mineralized diorite porphyry stock crops out within the western fork of Bearskin Creek.

The sulfide system as exposed is approximately 2 by 4 miles (Fields, 1977). Pyrite and chalcopyrite occur in highly shattered and fractured rocks throughout the area as fracture fillings, veinlets, and disseminations. Some of the better copper mineralization appears to occur within the sandstone and grit units of the Naknek Formation. The sulfide content of the sedimentary rocks varies from 3 to 10 percent with a high pyrite to chalcopyrite ratio. Within the diorite sulfide content is 1 to 2 percent.

Secondary biotite is present within the copper-bearing areas and beyond. Chlorite is ubiquituous throughout the area in all rock types. Sericite occurs as veinlet selvages and within the higher sulfide areas on the periphery of the system. Other peripheral alteration minerals include epidote, kaolinite, montmorillonite, and pyrophyllite.

In the eastern fork of Bearskin Creek metal values ranged from 235 to 1500 ppm copper, 0.01 to 0.13 ppm gold, 4 to $30 \mathrm{ppm}$ molybdenum, 0 to $4.1 \mathrm{ppm}$ silver (Fields, 1977). 
These values outlined an area of 1500 by 3000 feet. In the diorite located in the western fork maximum values of 800 to $900 \mathrm{ppm}$ copper, 0.02 to $0.62 \mathrm{ppm}$ gold, and 2 to $26 \mathrm{ppm}$ molybdenum were obtained from an area of 1000 feet by 2000 feet.

\section{Alteration:}

Secondary biotite is present within the copper-bearing areas and beyond. Chlorite is present throughout the area in all rock types. Sericite is present as veinlet selvages and within the higher sulfide areas on the periphery of the system. Other periphery alteration minerals include epidote, kaolinite, montmorillonite, and pyrophyllite.

\section{Age of mineralization:}

Tertiary?

\section{Deposit model:}

Porphyry copper; porphyry copper-gold; porphyry copper-molybdenum (Cox and Singer, 1986; models 17, 20c, 21a)

\section{Deposit model number (After Cox and Singer, 1986 or Bliss, 1992):}

$17,20 \mathrm{c}, 21 \mathrm{a}$

Production Status: None

Site Status: Inactive

\section{Workings/exploration:}

Bear Creek mapped and sampled this site during the period 1975 to 1976 (Fields,1977). Maximum metal values obtained were 1500 ppm copper, 30 ppm molybdenum, and small amounts of precious metals.

\section{Production notes:}

\section{Reserves:}

\section{Additional comments:}

This site is on lands selected by the Bristol Bay Native Corporation.

\section{References:}

Fields, 1977; Cox and others, 1981.

Primary reference: Fields, 1977

Reporter(s): S.H. Pilcher (Anchorage)

Last report date: $2 / 8 / 00$ 


\section{Site name(s): Bee Creek; Dry Creek}

Site type: Prospect

ARDF no.: CG007

Latitude: 56.51

Quadrangle: CG C-2

Longitude: 158.39

\section{Location description and accuracy:}

This site is located in T. 42 S., R. 58 W., of the Seward Meridian, near the headwaters of an unnamed creek entering Dry Creek approximately 1 mile north of Chignik Bay (Bundtzen and others, 1982, locality 89; Cox and others, 1981, locality 3; Nokleberg and others, 1987, locality AP 12). Site location is accurate to within 1 mile.

\section{Commodities:}

Main: $\mathrm{Ag}, \mathrm{Au}, \mathrm{Cu}, \mathrm{Mo}$

Other: $\mathrm{Pb}, \mathrm{Zn}$

Ore minerals: Chalcopyrite, chrysocolla, galena, gold, malachite, molybdenite, pyrite, pyrrhotite, sphalerite

Gangue minerals: Gypsum, quartz

\section{Geologic description:}

At this prospect sedimentary units (sandstone, siltstone, argillite, and conglomerate) of the Jurassic Naknek Formation have been intruded by a small dacite stock, which is surrounded by a sulfide system and alteration halo covering approximately 2 square miles (Fields, 1977). The main intrusive is dacite, but quartz diorite, andesite, and quartz porphyry have also been reported. These intrusives are part of a nearly east-west trending linear belt extending from Weasel Mountain (CG008) on the east to Cathedral Creek (CG001) on the west. This prospect was explored by Bear Creek Mining Company in 1975 and 1976 and by Resource Associates of Alaska in 1979 and 1981.

The prospect was identified on the basis of silt and color anomalies at the headwaters of the unnamed creek. Clusters of arsenic, copper, gold, lead, silver, and zinc silt anomalies surround the deposit. The main mineralized area is in a steep cirque basin at elevations of 500 to 1500 feet. Work by Resource Associates of Alaska (Anderson and others, 1979) suggest that mineralization may extend southwest into the McKinsey Valley.

Mineralization occurs mainly peripheral to the dacite stock with the bulk of it in arkose, conglomerate, and quartzite. Resource Associates of Alaska (Anderson and others, 1979) claim that the hornfelsed sediments near the contact contain the best mineralization. Mineralization decreases towards the core of the intrusive. 
Chalcopyrite and pyrite occur within a stockwork of hairline fractures containing quartz-sulfide veinlets throughout an area 2000 feet in diameter. Disseminated chalcopyrite and pyrite occur in biotized hornfels and these sulfides replace mafic minerals in the dacite. Molybdenite is present as fine-grained disseminations within the quartz veinlets, within gypsum veinlets, and within chalcopyrite clots. Pyrite forms a halo on the periphery of the system. Some magnetite veins have been reported which appear to be early in the mineralization sequence and contain no associated sulfides. Veins containing lead and zinc values occur peripheral to the copper zone.

Within the copper zone richer surface samples contained 500 to 2000 ppm copper, 0.04 to 0.18 ppm gold, 20 to 220 ppm molybdenum, and 0.4 to $0.18 \mathrm{ppm}$ silver (Fields, 1977). Bear Creek drilled 5 holes in this zone in 1975-76. Four holes averaged 500-1200 ppm copper and 5-28 ppm molybdenum. The best hole averaged 0.25 percent copper, 0.01 percent molybdenum, and 0.06 ppm gold over 500 feet. In 1979 Resource Associates of Alaska discovered two areas of polymetallic quartz veins. Samples of this material contained up to 5700 ppm copper, 4.4 ppm gold, 1.18 percent lead, 530 ppm molybdenum, 4.2 ounces silver per ton, and 1.62 percent zinc (Anderson and others, 1979). A resource of 4.5 to 9 million tonnes grading 0.25 percent copper and 0.01 percent molybdenum has been estimated (Young and others, 1997).

An age of the mineralization has been determined at between 3.2 and 3.8 million years (Wilson, 1980).

Secondary biotite is widely distributed both within and outside of the chalcopyrite zone. It replaces mafics and forms fine-grained aggregates both in the pluton and in the surrounding sediments. The biotite zone centers on the stock and extends irregularly southward over an area of 1500 by 3400 feet. Discontinuous zones of sericitic alteration occur peripheral to the biotite zone and have been reported to be superimposed on the potassic and propylitic alteration. Propylitic alteration forms the outer alteration zone and is represented by chlorite and epidote. A strong zone of argillic alteration located between the phyllic and propylitic zones has been reported (Butherus and others, 1981).

\section{Alteration:}

The alteration at this prospect appears to be the classic porphyry type with a potassic core grading outward through phyllic, argillic, and propylitic alteration zones although these may not all be developed fully. The best copper mineralization is in the potassic zone.

\section{Age of mineralization:}

Pliocene.

\section{Deposit model:}

Porphyry copper; porphyry copper-molybdenum (Cox and Singer, 1986; models 17, 21a)

Deposit model number (After Cox and Singer, 1986 or Bliss, 1992):

$17,21 \mathrm{a}$

Production Status: None 
Site Status: Inactive

\section{Workings/exploration:}

In 1975-76 Bear Creek Mining Company did detailed mapping and sampling and drilled 5 holes totalling 1865 feet. Resource Associates of Alaska carried out exploration here in 1979 and 1981. Additional mapping and sampling was done by the U.S. Geological Survey in 1980 and 1981. The prospect contains an estimated resource of 4.5 to 9 million tonnes grading 0.25 percent copper, 0.01 percent molybdenum, and trace gold.

\section{Production notes:}

\section{Reserves:}

The prospect contains an estimated resource of 4.5 to 9 million tonnes grading 0.25 percent copper, 0.01 percent molybdenum, and trace gold.

\section{Additional comments:}

This prospect is located on land conveyed to or patented by the Bristol Bay Native Corporation.

\section{References:}

Fields, 1977; Anderson and others, 1979; Wilson, 1980; Cox and others, 1981; Butherus and others, 1981; Wilson and Cox, 1983; Nokleberg and others, 1987; Young and others, 1997.

Primary reference: Fields, 1977

Reporter(s): S.H. Pilcher (Anchorage)

Last report date: $2 / 8 / 00$ 


\section{Site name(s): Weasel Mountain}

Site type: Occurrence

ARDF no.: CG008

Latitude: 56.49

Quadrangle: CG B-1

Longitude: 158.19

\section{Location description and accuracy:}

This occurrence is located approximately 2 miles northwest of Weasel Mountain and 2 miles west of Hook Bay in T. 42 and 43 S., R. 56 and 57 W., of the Seward Meridian (Cox and others, 1981, locality 4; MacKevett and Holloway, locality 25?). Location is accurate to within 1 mile.

\section{Commodities:}

Main: $\mathrm{Cu}, \mathrm{Mo}$

Other: $\mathrm{Ag}, \mathrm{Au}, \mathrm{Pb}, \mathrm{Zn}$

Ore minerals: Chalcopyrite, galena, molybdenite, pyrite, sphalerite

Gangue minerals: Calcite, quartz, tourmaline

\section{Geologic description:}

The area of this site is underlain by strata of the Cretaceous Chignik Formation and by the interbedded sediments, volcaniclastics, and andesite of the Oligocene-Pliocene Meshik Formation.

Fields (1977) describes two major intrusive systems, a diorite porphyry dike or sill and a younger quartz porphyry mass. The diorite is approximately $1 / 2$ mile in width and extends in a northeast direction for more than a mile. The quartz porphyry intrudes the the diorite, extends in a northeast direction, and measures approximately 700 by 3000 feet in outcrop. Butherus (1981) reports these intrusive phases as occupying approximately two square miles. Large areas of hornfels have resulted from thermal metamorphism of the nearby sedimentary rock.

The site is marked by a color anomaly which contains 1 to 6 percent sulfides over an area 2 miles in long by 1 mile wide. Fields (1977) describes the sulfides as mostly fracture controlled, primarily along certain marginal zones of the diorite and quartz porphyry and in the metasediments to the west. Chalcopyrite and sparse molybdenite occur in the marginal areas of the diorite, mostly along northeast-trending fracture zones. The resulting copper anomaly is approximately 700 by 1500 feet and contains 500 to 2100 ppm copper. The molybdenum anomaly coincides in part with the copper but has a more easterly trend. This anomaly is approximately 1000 by 2000 feet and contains 22 to $160 \mathrm{ppm}$ 
molybdenum. Low gold values ( 0.04 to $0.18 \mathrm{ppm}$ ) coincide with the molybdenum. Diffuse peripheral lead-zinc values are present.

Alteration is diffuse with no strong focus on a core. A broad sericitic zone exists within the area of higher sulfide content. Sericite occurs pervasively and along fractures. Propylitic alteration in the sediments is patchy and consists of chlorite and epidote clots.

Butherus (1981) reports intrusive breccia near the head of a valley in the NW1/4 sec. 2, T. 43 S., R. 57 W., of the Seward Meridian. The breccia, approximately 800 feet in diameter, contains traces of chalcopyrite and sphalerite in a quartz-tourmaline matrix. Other minerals present include pyrite, calcite, and barite. One sample contained $>10,000 \mathrm{ppm}$ copper, $0.06 \mathrm{ppm}$ gold, $13 \mathrm{ppm}$ lead, $28 \mathrm{ppm}$ silver, and $1800 \mathrm{ppm}$ zinc. Three other samples contained up to $750 \mathrm{ppm}$ copper, 0.02 to $0.04 \mathrm{ppm}$ gold, and 1.2 to $11.4 \mathrm{ppm}$ silver.

\section{Alteration:}

Alteration consists of a broad sericitic zone within the area of higher sulfide content and a peripheral, patchy propylitic zone.

\section{Age of mineralization:}

Tertiary.

\section{Deposit model:}

Porphyry copper; porphyry copper-molybdenum (Cox and Singer, 1986; models 17, 21a)

\section{Deposit model number (After Cox and Singer, 1986 or Bliss, 1992):}

$17,21 \mathrm{a}$

Production Status: None

Site Status: Inactive

\section{Workings/exploration:}

Bear Creek Mining Company mapped and sampled this occurrence in 1975-1976, and Resource Associates of Alaska explored it in 1979 and 1981.

Copper values of 500 to $2100 \mathrm{ppm}$ occur in an area of 700 by 1500 feet. Molybdenum values of 22 to $160 \mathrm{ppm}$ occur in an area of 1000 by 2000 feet. Gold values are up to 0.18 ppm.

\section{Production notes:}

\section{Reserves:}

\section{Additional comments:}

This site is partially on land selected by the Bristol Bay Native Corporation.

\section{References:}

Fields, 1977; MacKevett and Holloway, 1977; Anderson and others, 1979; Butherus and others, 1981;Cox and others, 1981; Detterman and others, 1981; Young and others, 1997. 
Primary reference: Fields, 1977

Reporter(s): S.H. Pilcher (Anchorage)

Last report date: $2 / 8 / 00$ 


\section{Site name(s): Unnamed (on coast near Ilnik)}

Site type: Occurrence

ARDF no.: CG009

Latitude: 56.6

Quadrangle: CG C-5

Longitude: 159.6

\section{Location description and accuracy:}

This site represents beach placer deposits on the shore of Bristol Bay extending 3 miles to the southwest and 12 miles to the northeast of Ilnik Lake.

\section{Commodities:}

Main: Fe, Ti

Other:

Ore minerals: Ilmenite, magnetite

\section{Gangue minerals:}

\section{Geologic description:}

The Ilnik beach deposit is a long spit bordering low-lying shallow swamps and mudflats. The mile-wide spit is capped by extensive dunes. The sediment is generally sand or loose gravel. Thin surface veneers of magnetite and ilmenite occur along the strand line as surf and wind concentrates.

Berryhill (1963) collected samples from 25 auger holes along approximately 15 miles of beach. Concentrates of this material contained 2.5 to 57.4 pounds of iron and 0.6 to 11.5 pounds of titanium per cubic yard in the magnetic fraction. In the non-magnetic fraction the concentrates contained 0 to 2.1 pounds of titanium per cubic yard.

\section{Alteration:}

Age of mineralization:

Quaternary.

\section{Deposit model:}

Shoreline placer titanium (Cox and Singer, 1986; model 39c)

Deposit model number (After Cox and Singer, 1986 or Bliss, 1992):

$39 \mathrm{c}$ 
Production Status: None

Site Status: Inactive

\section{Workings/exploration:}

Twenty-five auger holes were drilled and the resulting samples were concentrated and analysed for iron and titanium. The magnetic fraction contained 2.5 to 57.4 pounds of iron and 0.6 to 11.5 pounds of titanium per cubic yard. The non-magmetic fraction contained 0 to 2.1 pounds titanium per cubic yard.

\section{Production notes:}

Reserves:

Additional comments:

This deposit is located on state land.

\section{References:}

Berryhill, 1963.

Primary reference: Berryhill, 1963

Reporter(s): S.H. Pilcher (Anchorage)

Last report date: $2 / 8 / 00$ 


\section{Site name(s): Foot Bay}

Site type: Occurrence

ARDF no.: CG010

Latitude: 56.048

Quadrangle: CG A-3

Longitude: 158.769

\section{Location description and accuracy:}

This mineral occurrence is insec. 2, T. 48 S., R. 61 W., of the Seward Meridian, approximately 2 miles west of Foot Bay, near the head of a small northeast-flowing drainage. The location is accurate to within $1 / 2$ mile.

\section{Commodities:}

Main: $\mathrm{Cu}$

Other: $\mathrm{Ag}, \mathrm{Au}, \mathrm{Mo}$

Ore minerals: Chalcopyrite, molybdenite, pyrite

\section{Gangue minerals:}

\section{Geologic description:}

This site is marked by a color anomaly which occupies an area of approximately $1 / 2$ by 1 mile along the northern contact zone of a small diorite stock (Fields, 1977). The stock intrudes siltstone, sandstone, grit, and conglomerate of the Cretaceous Hodoo Formation, which exhibits strong hornfelsing near the contact zone.

A peripheral pyrite-bearing fracture zone is present along the northern contact. The sulfide content in this zone is up to 5 percent, whereas the intrusive contains 1 percent or less sulfides (Fields, 1977).

Two rock samples collected by Bear Creek Mining Company in 1976 contained values of about 230 ppm copper and 2 ppm molybdenum along with traces of lead, zinc, and precious metals. One high-grade sample collected near the contact had metal values of 2300 ppm copper, 1.9 ppm gold, 2 ppm molybdenum, and 4.6 ppm silver.

\section{Alteration:}

\section{Age of mineralization:}

Tertiary.

\section{Deposit model:}

Porphyry copper; porphyry copper-molybdenum (Cox and Singer, 1986; models 17, 21a) 
Deposit model number (After Cox and Singer, 1986 or Bliss, 1992):

$17,21 \mathrm{a}$

Production Status: None

Site Status: Inactive

\section{Workings/exploration:}

This site was briefly examined and sampled by Bear Creek Mining Company in 1976 (Fields, 1977). Two of the rock samples contained about 230 ppm copper and 2 ppm molybdenum along with minor base and precious values. A high-grade sample collected near the contact had metal values of 2300 ppm copper, $1.9 \mathrm{ppm}$ gold, $2 \mathrm{ppm}$ molybdenum, and 4.6 ppm silver.

\section{Production notes:}

\section{Reserves:}

\section{Additional comments:}

This mineral occurrence is located within the Alaska Peninsula National Wildlife Refuge.

\section{References:}

Fields, 1977.

Primary reference: Fields, 1977

Reporter(s): S.H. Pilcher (Anchorage)

Last report date: $2 / 8 / 00$ 


\section{Site name(s): Home Creek}

Site type: Occurrence

ARDF no.: CG011

Latitude: 56.242

Quadrangle: CG A-3

Longitude: 158.701

\section{Location description and accuracy:}

This site is located in sec. 31, T. 45 S., R. 60 W., of the Seward Meridian, approximately 2.5 miles northeast of Home Creek and 1 mile south of the Chignik River (Cox and others, 1981, locality 7). Location is accurate to within $1 / 2$ mile.

\section{Commodities:}

Main: $\mathrm{Ag}, \mathrm{Pb}, \mathrm{Zn}$

Other: $\mathrm{Cu}, \mathrm{Mo}$

Ore minerals: Chalcopyrite, galena, molybdenite, pyrite, sphalerite

\section{Gangue minerals: Quartz}

\section{Geologic description:}

This occurrence is a large color anomaly up to 1.5 miles wide which extends approximately 4 miles northeast from Home Creek towards Chignik Lagoon (Fields, 1977). The color is coincident with an area of pyritization and propylitization which may be related to a Tertiary dacite dike (Detterman and others, 1981) having a similar trend. The altered rocks are part of the Tolstoi Formation of Eocene and Paleocene age.

Several large quartz veins, up to 10 feet wide, were discovered by Bear Creek Mining Company during the period 1975-1976 (Fields, 1977). These were observed to carry galena and rare pyrite. A chip sample contained 120 ppm copper, 6270 ppm lead, 11.6 ppm molybdenum, 19.2 ppm silver, and 1600 ppm zinc. Massive quartz float containing sphalerite and disseminated pyrite was reported by Resource Associates of Alaska in 1979. It contained 490 ppm copper, 190 ppm lead, 5.5 ppm silver, and 4400 ppm zinc (Anderson and others, 1979).

\section{Alteration:}

Sedimentary units of the Tolstoi Formation exhibit propylitization.

\section{Age of mineralization:}

Tertiary. 
Deposit model:

Polymetallic vein (Cox and Singer, 1986; model 22c)

Deposit model number (After Cox and Singer, 1986 or Bliss, 1992):

$22 \mathrm{c}$

Production Status: None

Site Status: Inactive

Workings/exploration:

This occurrence was briefly examined by Bear Creek Mining Company in 1975-1976. A vein chip sample contained 120 ppm copper, 6270 ppm lead, 11.6 ppm molybdenum, $19.2 \mathrm{ppm}$ silver, and $1600 \mathrm{ppm}$ zinc. Resource Associates of Alaska examined the area in 1979. They reported massive quartz float that contained 490 ppm copper, $190 \mathrm{ppm}$ lead, 5.7 ppm silver, and 4400 ppm zinc.

\section{Production notes:}

\section{Reserves:}

\section{Additional comments:}

A part of this site is on land conveyed to or patented by the Bristol Bay Native Corporation. The remainder is within Alaska Peninsula National Wildlife Refuge.

\section{References:}

Fields, 1977; Anderson and others, 1979; Cox and others, 1981; Detterman and others, 1981.

Primary reference: Fields, 1977

Reporter(s): S.H. Pilcher (Anchorage)

Last report date: $2 / 8 / 00$ 
Site name(s): Windy Bay

Site type: Occurrence

ARDF no.: CG012

Latitude: 56.143

Quadrangle: CG A-3

Longitude: 158.779

\section{Location description and accuracy:}

This site is approximately 2 miles west of the head of the north arm of Windy Bay and includes the headwaters of streams draining into that head of the bay (Cox and others, 1981, locality 9). The site is accurate as plotted.

\section{Commodities:}

Main: $\mathrm{Cu}, \mathrm{Mo}$

Other: $\mathrm{Au}, \mathrm{Pb}, \mathrm{Zn}$

Ore minerals: Chalcopyrite, galena, gold, molybdenite, pyrite, pyrrhotite, sphalerite

Gangue minerals: Chlorite, quartz

\section{Geologic description:}

The geologic setting at this site consists of a quartz diorite stock which has intruded sedimentary units of the Jurassic Naknek Formation (Fields, 1977). These units include grits, graywacke, siliceous siltstone, and black shale.

A discontinuous color anomaly is present along the inferred contact zone (Fields, 1977). The sediments near the contact have been hornfelsed and contain pyrrhotite, pyrite, rare chalcopyrite, and magnetite as disseminations and as veinlet and fracture fillings. Total sulfide content is $1-5$ percent. Sulfides occur up to 1000 feet from the contact.

The sulfide content of the intrusive is 1 percent or less. Chalcopyrite is present on fracture surfaces and in quartz-chlorite and pyrite veinlets. These strike approximately N 25 $\mathrm{W}$ and cover an area of 1000 by 4000 feet.

Samples of the mineralized intrusive contained up to 424 ppm copper, $0.13 \mathrm{ppm}$ gold, 32 ppm lead, 25 ppm molybdenum, and 9 ppm zinc (Fields, 1977).

The intrusive exhibits local chloritization along with scattered patches of epidote and secondary biotite. The hornfelsed sediments have been silicified and contain secondary biotite and minor chlorite.

\section{Alteration:}

Alteration in the intrusive consists of local zones containing chlorite, epidote, and secondary biotite. The sediments near the intrusive contact have been hornfelsed, silicified, 
and contain chlorite and secondary biotite.

\section{Age of mineralization:}

Tertiary.

\section{Deposit model:}

Porphyry copper; porphyry copper-gold; porphyry copper-molybdenum (Cox and Singer, 1986; models 17, 20c, 21a)

Deposit model number (After Cox and Singer, 1986 or Bliss, 1992):

$17,20 \mathrm{c}, 21 \mathrm{a}$

Production Status: None

Site Status: Inactive

\section{Workings/exploration:}

Bear Creek Mining Company briefly explored this site during the period 1975-1976.

The few samples collected contained up to 424 ppm copper, $0.13 \mathrm{ppm}$ gold, $32 \mathrm{ppm}$ lead, 25 ppm molybdenite, and 9 ppm zinc (Fields, 1977).

Resource Associates of Alaska briefly sampled this occurrence in 1979 (Anderson and others, 1979).

\section{Production notes:}

\section{Reserves:}

\section{Additional comments:}

This site is partially on land selected by the Bristol Bay Native Corporation. The remainder is within the Alaska Peninsula National Wildlife Refuge.

\section{References:}

Fields, 1977; Anderson and others, 1979; Cox and others, 1981.

Primary reference: Fields, 1977

Reporter(s): S.H. Pilcher (Anchorage)

Last report date: $2 / 8 / 00$ 


\section{Site name(s): Unnamed (south of mouth of Fishhook Bay)}

Site type: Occurrence

ARDF no.: CG013

Latitude: 56.004

Quadrangle: CG A-2

Longitude: 158.644

\section{Location description and accuracy:}

This occurrence is located in T. 48 S., R. 60 W., of the Seward Meridian, approximately 1.3 miles south of the mouth of Fishook Bay. The location is accurate to within 1/2 mile.

\section{Commodities:}

Main: $\mathrm{Ag}, \mathrm{Cu}, \mathrm{Pb}, \mathrm{Zn}$

Other: $\mathrm{As}, \mathrm{Sb}$

Ore minerals: Arsenopyrite?, chalcopyrite?, galena?, pyrite, sphalerite?

Gangue minerals: Quartz

\section{Geologic description:}

The rocks at this site consist of Cretaceous Hoodoo Formation cut by andesite dikes. The U.S. Geological Survey sampled a pyritic quartz vein which cuts hornfelsed siltstone of the Hoodoo Formation at this site (Angeloni and others, 1985). The width of the vein is unknown. The sample of vein material ran $200 \mathrm{ppm}$ antimony, >10,000 ppm arsenic, 1,500 ppm copper, 1,500 ppm lead, 150 ppm silver; and >10,000 ppm zinc.

\section{Alteration:}

Age of mineralization:

Tertiary?

Deposit model:

Polymetallic vein (Cox and Singer, 1986; model 22c)

Deposit model number (After Cox and Singer, 1986 or Bliss, 1992): $22 \mathrm{c}$

Production Status: None

Site Status: Inactive 


\section{Workings/exploration:}

Rock sample (83AWs 57) of vein material collected by the U.S. Geological Survey contained 200 ppm antimony, >10,000 ppm arsenic, 1,500 ppm copper, 1,500 ppm lead, 150 ppm silver, and >10,000 ppm zinc.

\section{Production notes:}

\section{Reserves:}

\section{Additional comments:}

This site is located within the Alaska Peninsula National Wildlife Refuge.

\section{References:}

Angeloni and others, 1985.

Primary reference: Angeloni and others, 1985

Reporter(s): S.H. Pilcher (Anchorage)

Last report date: $2 / 8 / 00$ 
Site name(s): Unnamed (near the head of Portage Bay)

Site type: Occurrence

ARDF no.: CG014

Latitude: 56.21

Quadrangle: CG A-3

Longitude: 158.61

Location description and accuracy:

This site is located near the head of Portage Bay (MacKevett and Holloway, 1977, locality 5). Site location is accurate to within 2 miles.

Commodities:

Main: $\mathrm{Cu}$

Other: Ag

Ore minerals:

Gangue minerals:

Geologic description:

The area is underlain by volcanic rocks of the Meshik Formation of Oligocene and Eocene ages (Detterman and others, 1981). MacKevett and Holloway (1977) indicate alteration and porphyry type mineralization possibly associated with Tertiary intrusives.

\section{Alteration:}

Age of mineralization:

Tertiary.

\section{Deposit model:}

Porphyry copper? (Cox and Singer, 1986; model 17)

Deposit model number (After Cox and Singer, 1986 or Bliss, 1992):

17 ?

Production Status: None

Site Status: Inactive

Workings/exploration: 
U.S. Bureau of Mines records indicate claims were staked on this occurrence in the mid-1960's.

\section{Production notes:}

Reserves:

Additional comments:

This site is located on land conveyed to or patented by the Bristol Bay Native Corporation.

\section{References:}

U.S. Bureau of Mines, 1973; MacKevett and Holloway, 1977.

Primary reference: MacKevett and Holloway, 1977

Reporter(s): S.H. Pilcher (Anchorage)

Last report date: $2 / 8 / 00$ 


\section{Site name(s): Unnamed (at the head of Kuiukta Bay)}

Site type: Occurrence

ARDF no.: CG015

Latitude: 56.19

Quadrangle: CG A-2

Longitude: 158.51

Location description and accuracy:

This occurrence is located in T. 46 S., R. 59 W., of the Seward Meridian. It is at the head of Kuiukta Bay (MacKevett and Holloway, 1977, locality 6). Site location is accurate to within 1 mile.

\section{Commodities:}

Main: $\mathrm{Cu}$

Other: $\mathrm{Ag}, \mathrm{Au}, \mathrm{Pb}$

Ore minerals:

Gangue minerals:

Geologic description:

This site appears to be underlain by a Tertiary pluton (Detterman and others, 1981). MacKevett and Holloway (1977) suggest that this occurrence is a porphyry-type deposit associated with an altered Tertiary intrusion. The U.S. Bureau of Mines (1973) lists the commodities at this site as gold, lead, and silver and indicates that claims were active here during the mid-1960's.

\section{Alteration:}

Age of mineralization:

Tertiary.

Deposit model:

Porphyry copper? (Cox and Singer, 1986; model 17)

Deposit model number (After Cox and Singer, 1986 or Bliss, 1992):

17 ?

Production Status: None 
Site Status: Inactive

Workings/exploration:

There were active claims at this site in the mid-1960's (U.S. Bureau of Mines, 1973)

Production notes:

\section{Reserves:}

Additional comments:

This site is located within the Alaska Peninsula National Wildlife Refuge.

\section{References:}

U.S. Bureau of Mines, 1973; MacKevett and Holloway, 1977.

Primary reference: U.S. Bureau of Mines, 1973

Reporter(s): S.H. Pilcher (Anchorage)

Last report date: $2 / 8 / 00$ 


\section{Site name(s): Unnamed (west of Bearskin Gulch)}

Site type: Occurrence

ARDF no.: CG016

Latitude: 56.2

Quadrangle: CG A-4

Longitude: 159.1

Location description and accuracy:

The approximate location of this mineral occurrence is in T. 45 S., R. 63 W., of the Seward Meridian, 7 miles northwest of the headwaters of Clark River and 1 1/2 miles west of Bearskin Gulch (MacKevett and Holloway, 1977, locality 23). Site location is accurate to within 5 miles.

\section{Commodities:}

Main: $\mathrm{Cu}$ ?

Other:

Ore minerals:

Gangue minerals:

Geologic description:

This site has been described as a large altered zone in Tertiary intrusive rocks (MacKevett and Holloway, 1977).

\section{Alteration: \\ Age of mineralization: \\ Tertiary.}

Deposit model:

Deposit model number (After Cox and Singer, 1986 or Bliss, 1992):

Production Status: None

Site Status: Inactive

Workings/exploration: 


\section{Production notes:}

\section{Reserves:}

\section{Additional comments:}

This mineral occurrence is located within the Alaska Peninsula National Wildlife Refuge.

\section{References:}

MacKevett and Holloway, 1977.

Primary reference: MacKevett and Holloway, 1977

Reporter(s): S.H. Pilcher (Anchorage)

Last report date: $2 / 8 / 00$ 
Site name(s): Unnamed (between arms of Castle Bay)

Site type: Occurrence

ARDF no.: CG017

Latitude: 56.21

Quadrangle: CG A-1

Longitude: 158.31

Location description and accuracy:

This site is located approximately on the point between the northwest and southwest arms of Castle Bay (MacKevett and Holloway, 1977, locality 26). Site location is accurate to within 2 miles.

\section{Commodities:}

Main: $\mathrm{Cu}$

Other: Ag, Mo

Ore minerals: Chalcopyrite, molybdenite?

Gangue minerals:

Geologic description:

This site is described as an altered zone in Tertiary intrusive and volcanic rocks (MacKevett and Holloway, 1977). Fields (1977) reports a 3/4-square-mile color anomaly associated with a small quartz diorite body in this general area. A silt sample collected by Bear Creek Mining Company from a northeast-flowing drainage approximately 1 mile west of the site as plotted contained 138 ppm copper and 3.4 ppm molybdenum. Sparse chalcopyrite was noted in quartz diorite boulders.

\section{Alteration:}

Age of mineralization:

Tertiary.

\section{Deposit model:}

Porphyry copper? (Cox and Singer, 1986; model 17)

Deposit model number (After Cox and Singer, 1986 or Bliss, 1992): 17 ?

Production Status: None 
Site Status: Inactive

Workings/exploration:

Bear Creek Mining Company did limited exploration at this occurrence during the period 1975-1976.

\section{Production notes:}

\section{Reserves:}

\section{Additional comments:}

This site is located on land conveyed to or patented by the Bristol Bay Native Corporation.

\section{References:}

MacKevett and Holloway, 1977; Fields, 1977.

Primary reference: Fields, 1977

Reporter(s): S.H. Pilcher (Anchorage)

Last report date: $2 / 8 / 00$ 


\section{Site name(s): Unnamed (in Knife Peak area)}

Site type: Occurrence

ARDF no.: CG018

Latitude: 56.27

Quadrangle: CG B4

Longitude: 159.09

Location description and accuracy:

This site is located on or near Knife Peak, approximately 8 miles west of Chignik Lake (MacKevett and Holloway, 1977, locality 24). Site location is accurate to within 2 miles.

\section{Commodities:}

Main: $\mathrm{Cu}$ ?

Other:

Ore minerals:

Gangue minerals:

Geologic description:

This site is marked by a color anomaly approximately 1 by 3 miles in extent (Cox and others, 1981). It has been described as a porphyry-type occurrence in Tertiary intrusive rocks (MacKevett and Holloway, 1977). This occurrence may be related to a dacite plug dome (Detterman and others, 1981). Nearby drainages are anomalous in tin and zinc.

\section{Alteration:}

Age of mineralization:

Tertiary.

Deposit model:

Porphyry copper? (Cox and Singer, 1986; model 17)

Deposit model number (After Cox and Singer, 1986 or Bliss, 1992):

$17 ?$

Production Status: None

Site Status: Inactive 
Workings/exploration:

Production notes:

Reserves:

Additional comments:

This site is located within the Alaska Peninsula National Wildlife Refuge.

References:

MacKevett and Holloway, 1977.

Primary reference: MacKevett and Holloway, 1977

Reporter(s): S.H. Pilcher (Anchorage)

Last report date: $2 / 8 / 00$ 


\section{Site name(s): Unnamed (west of Hook Bay)}

Site type: Occurrence

ARDF no.: CG019

Latitude: 56.5

Quadrangle: CG C1

Longitude: 158.2

Location description and accuracy:

The approximate location of this site is in T. 42 S., R. 57 W., of the Seward Meridian, several miles west of Hook Bay (MacKevett and Holloway, 1977, locality 25). It may be a part of the Weasel Mountain prospect (CG008). Location is accurate to within 3 miles.

\section{Commodities:}

Main: $\mathrm{Cu}, \mathrm{Zn}$

Other:

Ore minerals:

Gangue minerals:

Geologic description:

This site is described as a porphyry-type occurrence represented by altered zones in sedimentary rocks of the Jurassic Naknek Formation and in Tertiary diorite and dacite (MacKevett and Holloway, 1977; Detterman and others, 1981).

\section{Alteration:}

Age of mineralization:

Tertiary.

Deposit model:

Porphyry copper? (Cox and Singer, 1986; model 17)

Deposit model number (After Cox and Singer, 1986 or Bliss, 1992):

$17 ?$

Production Status: None

Site Status: Inactive 
Workings/exploration:

Production notes:

Reserves:

Additional comments:

Depending on exact location this site may be on lands selected by the Bristol Bay Native Corporation or may be within the Alaska Peninsula National Wildlife Refuge.

References:

MacKevett and Holloway, 1977; Detterman ans others, 1981.

Primary reference: MacKevett and Holloway, 1977

Reporter(s): S.H. Pilcher (Anchorage)

Last report date: $2 / 8 / 00$ 


\section{Site name(s): Unnamed (Between Portage Bay and Chignik Lake)}

Site type: Occurrence

ARDF no.: CG020

Latitude: 56.2

Quadrangle: CG A-3

Longitude: 158.7

Location description and accuracy:

This site's approximate location is between Portage Bay and Chignik Lake in T. 46 S., R. 60 W., of the Seward Meridian (MacKevett and Holloway, 1977, locality 22). This site may be related to or part of the Home Creek occurrence (CG011). The site location as plotted is accurate to within 3 miles.

\section{Commodities:}

Main: $\mathrm{Cu}$ ?

Other:

Ore minerals:

Gangue minerals:

\section{Geologic description:}

This site has been described as consisting of extensive altered zones in composite Tertiary plutons which are weakly mineralized (MacKevett and Holloway, 1977).

\section{Alteration:}

Age of mineralization:

Tertiary.

Deposit model:

Porphyry copper? (Cox and Singer, 1986; model 17)

Deposit model number (After Cox and Singer, 1986 or Bliss, 1992):

$17 ?$

Production Status: None

Site Status: Inactive 
Workings/exploration:

Production notes:

Reserves:

Additional comments:

Depending on its exact location this site may be located on land conveyed to or patented by the Bristol Bay Native Corporation or it may be within the Alaska Peninsula National Wildlife Refuge.

\section{References:}

MacKevett and Holloway, 1977.

Primary reference: MacKevett and Holloway, 1977

Reporter(s): S.H. Pilcher (Anchorage)

Last report date: $2 / 8 / 00$ 


\section{Site name(s): Unnamed (on Braided Creek)}

Site type: Prospect

ARDF no.: CG021

Latitude: 56.5

Quadrangle: CG C-2

Longitude: 158.5

Location description and accuracy:

This site consists of gold placer claims whose approximate location is on Braided Creek in T. 42 S., R. 58 W., of the Seward Meridian (MacKevett and Holloway, 1977, locality 20). Site location is accurate to within 3 miles.

\section{Commodities:}

Main: $\mathrm{Au}$

Other:

Ore minerals: Gold

Gangue minerals:

Geologic description:

This site represents gold placer claims indicated on 1973 U.S. Bureau of Mines maps.

\section{Alteration:}

Age of mineralization:

Quaternary.

Deposit model:

Placer gold-PGE (Cox and Singer, 1986; model 39a)

Deposit model number (After Cox and Singer, 1986 or Bliss, 1992):

$39 \mathrm{a}$

Production Status: Undetermined.

Site Status: Inactive

Workings/exploration:

There has been no post-1950 activity. 
Production notes:

Reserves:

Additional comments:

This site is located within the Alaska Peninsula National Wildlife Refuge.

\section{References:}

MacKevett and Holloway, 1977; U.S. Bureau of Mines, 1973.

Primary reference: MacKevett and Holloway, 1977

Reporter(s): S.H. Pilcher (Anchorage)

Last report date: $2 / 8 / 00$ 
Site name(s): Unnamed (south of Chignik)

Site type: Occurrence

ARDF no.: CG022

Latitude: 56.27

Quadrangle: CG B-2

Longitude: 158.39

Location description and accuracy:

The approximate location of this occurrence is 1.5 miles south of the village of Chignik (Fields, 1977, locality 8). Site is accurate to within 2 miles.

\section{Commodities:}

Main:

Other:

Ore minerals: Pyrite, pyrrhotite

Gangue minerals:

\section{Geologic description:}

This site represents a 3-square-mile color anomaly which generally corresponds in location to a Tertiary quartz diorite stock containing up to 0.25 percent disseminated pyrite. The stock cuts sedimentary rocks of the Tolstoy Formation (Eocene and Paleocene age). The siltstones and sandstones near the intrusive are hornfelsed and carry up to 5 percent pyrrhotite (Fields, 1977).

\section{Alteration:}

Age of mineralization:

Tertiary.

\section{Deposit model:}

Porphyry copper? (Cox and Singer, 1986; model 17)

Deposit model number (After Cox and Singer, 1986 or Bliss, 1992):

$17 ?$

Production Status: None

Site Status: Inactive 
Workings/exploration:

The area was examined by Bear Creek Mining Company during the period 1975-1976 (Fields, 1977).

Production notes:

\section{Reserves:}

Additional comments:

This site is located on land conveyed to or patented by the Bristol Bay Native Corporation.

\section{References:}

Fields, 1977.

Primary reference: Fields, 1977

Reporter(s): S.H. Pilcher (Anchorage)

Last report date: $2 / 8 / 00$ 


\section{References}

Alaska Division of Natural Resources, 1997, State of Alaska General Land Status with Mineral Resources and Mining Claims, Alaska Peninsula, 1 map sheet, scale 1:1,000,000.

Alaska Earth Science, 1997, Mineral and oil and gas potential of the Bristol Bay region, southwestern Alaska: prepared for the Bristol Bay Native Corporation, 11 p. (held by Alaska Earth Science).

Anderson, G.D., Fitch, G.M., Lappie, D.W., Lindberg, P.A., and Fankhauser, R.E., 1979, Exploration and evaluation of Bristol Bay Native Corporation Lands, Vol. II, Book 1: prepared for Houston Oil and Minerals Company by Resource Associates of Alaska, 78 p. (held by Alaska Earth Science).

Angeloni, L.M., Wilson, F.H., and Sutley, S., 1985, Map and tables showing preliminary rock geochemical data, Port Moller, Stepovak Bay, and Simeonof Island quadrangles, Alaska: U.S. Geological Survey OpenFile Report 85-470, 179 p., 1 map sheet, scale 1:250,000.

Atwood, W. W., 1909, Mineral resources of southwest Alaska, in Brooks, A.H., and others, Mineral resources of Alaska in 1908: U.S. Geological Survey Bulletin 379, 411 p.

Atwood, W. W., 1911, Geology and mineral resources of parts of the Alaska Peninsula: U.S. Geological Survey Bulletin 467, 137 p.

Berryhill, R.V., 1963, Reconnaissance of beach sands, Bristol Bay, Alaska: U.S. Bureau of Mines Report of Investigations $6214,48 \mathrm{p}$.

Berg, H.C., and Cobb. E.H., 1967, Metalliferous lode deposits of Alaska: U.S. Geological Survey Bulletin 1246, $254 \mathrm{p}$.

Brown, D.L., Crabtree, E.H., and Smith, F.L., 1965, Mineralogic study of a complex sulfide deposit, vein number 1, project Manhatten, Alaska: Prepared for Pan American Petroleum Corporation by The Colorado School of Mines Foundation Inc., 55 p. (held by Alaska Earth Science).

Bundtzen, T. K., Swainbank, R.C., Clough, A.H., Henning, M.W., and Hansen, E.W., 1984, Alaska's mineral industry in 1983: Alaska Division of Geological and Geophysical Surveys Special Report 33, 56 p.

Butherus, D.L., White, D.C., Smith, W.H., Radford, G., Sandberg, R.J., and Pray, J.C., 1981, Exploration and evaluation of precious metal potential of Bristol Bay Native Corporation Lands, southwest Alaska, 1981, Vol. 1: prepared for Nerco by Resource Associates of Alaska, 90 p. (held by Alaska Earth Science).

Cobb, E.H., and Kachadoorian, R., 1961, Index of metallic and non-metallic mineral deposits of Alaska compiled from published reports of federal and state agencies through 1959: U.S. Geological Survey Bulletin $1139,363 \mathrm{p}$.

Cobb, E.H., 1972, Metallic mineral resource map of the Chignik quadrangle, Alaska: U. S. Geological Survey Map MF-374, 1 map sheet, scale 1:250,000.

Cobb, E.H., 1973, Placer deposits of Alaska: U.S. Geological Survey Bulletin 1374, 213 p.

Cobb, E. H., 1980, Summaries of data on and lists of references to metallic and selected non-metallic mineral deposits in fifteen quadrangles in southwestern and west-central Alaska: U.S. Geological Survey Open-File Report 80-909, 103 p.

Cox, D.P., Detra, D.E., and Detterman, R.L., 1981, Mineral resource maps of the Chignik and Sutwik Island quadrangles, Alaska: U.S. Geological Survey Map MF- 1053K, 2 map sheets, scale 1:250,000. 
Cox, D.P., and Singer, D.A., eds., 1986, Mineral deposit models: U.S. Geological Survey Bulletin 1693, $379 \mathrm{p}$.

Detterman, R.L., Miller, T.P., Yount, M.E., and Wilson, F.H.,1981, Geologic map the Chignik and Sutwik Island quadrangles Alaska: U.S. Geologic Survey Map I- 1229, 1 map sheet, scale 1:250,000.

Fields, E.D., 1977, 1976 Annual report, Alaska search, Chignik area, Bristol Bay region: Bear Creek Mining Company, $44 \mathrm{p}$.

Hollister, V.F., 1978, Geology of the porphyry copper deposits of the western hemisphere: Society of Mining Engineers, $219 \mathrm{p}$.

Knappen, R.S., 1929, Geology and mineral resources of the Aniakchak District, in Smith, P.S., and others, Mineral Resources of Alaska in 1926: U.S. Geological Survey Bulletin 797, 227 p.

MacKevett, E.M., and Holloway, C.D., 1977, Table describing metalliferous mineral deposits in the western part of southern Alaska: U.S. Geological Survey Open-File Report 77-0169F, 38 p., 1 map sheet, Scale $1: 1,000,000$.

Nokleberg, W.J., Bundtzen, T.K., Berg, H.C., Brew, D.A., Grybeck, D., Robinson, M.S., Smith, T.E., and Yeend, W., 1987, Significant metallferous lode and placer deposits of Alaska; U.S. Geological Survey Bulletin $1786,104 \mathrm{p}$.

Ransome, A.L., and Kerns, W.H., 1954, Names and definitions of regions, districts, and subdistricts in Alaska: U. S. Bureau of Mines Information Circular 7679, $91 \mathrm{p}$.

Sillitoe, R.H., 1990, Metallogenetic setting and gold potential of the Chignik and Iliamna regions, Alaska Peninsula: A report prepared for Western Gold Exploration and Mining Company Limited, 9 p.(held by Alaska Earth Science).

Smith, W.R., and Baker, A.H., 1924, The Cold Bay-Chignik district, in Brooks, A.H., and others, Mineral resources of Alaska in 1922: U.S. Geological Survey Bulletin 755, 222 p.

U.S. Bureau of Mines, 1973, Quadrangle map overlays showing mineral deposit locations in Alaska: U.S. Bureau of Mines Open-File Report 20-73, 95 map sheets, scale 1:250,000.

Wilson, F.H., 1980, Late Mesozoic and Cenozoic tectonics and age of porphyry copper prospects, Chignik and Sutwik Island quadrangles, Alaska Peninsula: U.S. Geological Survey Open-File Report 80-543, 94 p., 4 map sheets, scales 1:250,000 and 1000 feet to the inch.

Wilson, F.H., and Cox, D.P., 1983, Geochronology, geochemistry, and tectonic environment of porphyry mineralization in the central Alaska Peninsula: U.S. Geological Survey Open-File Report 83-783, 24 p.

Young, L.E., St. George, P., and Bouley, B.A, 1997, Porphyry copper deposits in relation to the magmatic history and palinspastic restoration of Alaska, in Goldfarb, R.J., and Miller, L.D., eds., Mineral Deposits of Alaska: Economic Geology Monograph 9, 482 p. 